\title{
Gendered character of barrenness in an African context: An African pastoral study
}

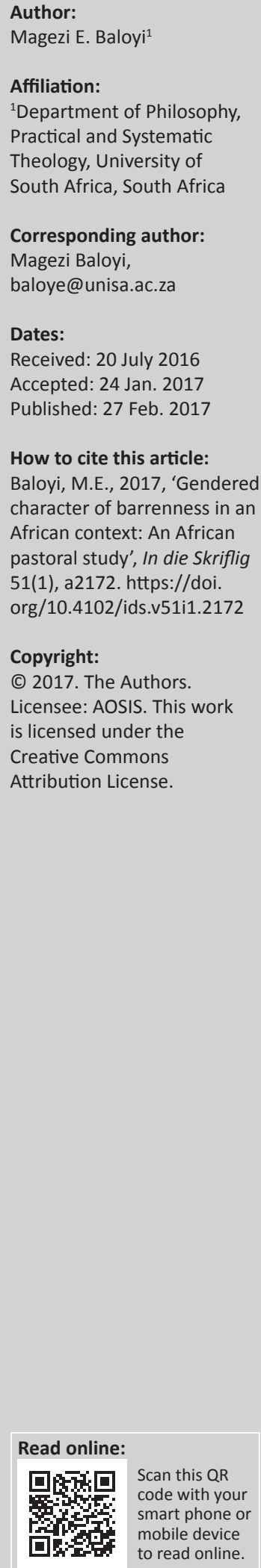

\begin{abstract}
The importance of children for African people has been prioritised above many other reasons for marriage. Besides the fact that every childless marriage has only a slim chance of survival, women are the main objects of this pressure. Some African researchers have revealed that it is usually women who are traditionally held responsible for childlessness. It becomes evident when a man takes a second wife without first seeking medical proof of his wife's barrenness. In other instances, suspicions force men to divorce women or claim their bride price back as a result of childlessness. Besides being a humiliation for women, it is also a gender inequality issue that deserves theological attention and research to make suggestions and advise on how to reduce or eliminate some practices that promote the subjection of women. The purpose of this article is to research how gender inequality and women abuse continue to manifest because of barrenness. A theoretical framework will direct the research methods - the reading of African-based books, articles, newspapers and other relevant media sources will be utilised.
\end{abstract}

\section{Introduction}

The statement 'Woman's glory is crowned in childbirth' pressurises African women to go to great lengths to conceive a child of their own, according to Kimathi (1994:82). The statement suggests that it is the woman who is under pressure to conceive and give birth. One man, while beating his wife was quoted as yelling: 'All that comes out of your vagina is nothing but blood' (Phoofolo 2007:381). This statement characterised a husband who was tired to see his wife continuing in her menstruation periods, which means she is not falling pregnant as expected. For me this was quick judgement by some African males towards their wives when conception does not occur. According to Kimathi (1994:83), it was this kind of frustration that led the husband and the wife to reach an agreement to bring another woman or girl (particularly from the wife's siblings or relatives) to bear children - a form of polygamy that Kalu (2005:53), citing Mugambi, argues would occur and be accepted. Alternatively, Mbiti (1969:133) indicates that divorce was also a solution when the marriage did not produce children. Mbiti (1969:104) goes on to say: 'It is believed in many African societies that from the very beginning of human life, God commanded or taught people to get married and bear children.'

The problem is that, instead of childbearing being part of the joy of the family, it is made a burden that sometimes entrenches wife beating (Fidgen 2009; Baloyi 2012) and even women killings (Baloyi 2013; Admin 2010). Chigudu (2004) argues how childlessness entrenched wife beating in Zimbabwe:

Georgia's husband battered her for eleven years because they couldn't have children. Her father-in-law
finally threw her out because she had 'disgraced her family'. Being unable to have children is considered
a crime. (p. 107)

This is why, in this incident, wife beating and being thrown out of the house served the purpose of punishing the guilty. It is because of this agreement that Waruta and Kinoti (2000:129) and Sophanna (2006:88) argue that barrenness ${ }^{1}$ is one of the reasons why wives are beaten and battered in an African context. According to Donkor (2008:22), childless women usually encounter unfavourable treatment from their society. A woman might be expelled from her husband's house either by the husband himself or by his family. A husband could be encouraged to take other wives if a wife is suspected of barrenness.

Among many other reasons, some African perspectives indicate that the challenge of barrenness is often traditionally used as a weapon of subjection and abuse. This is evidenced by Turaki (1999:106) who says that by accepting the bride price, parents are signing a contract that the girl 
will bear children and failure to do so will lead to the husband claiming back the bride price. Kimathi (1994:12) states that it is expected of every normal woman to bear children, otherwise the woman is rendered abnormal. One of the social stigmas clinging to women is that social pressures on women to procreate have existed for a long time. There is scholarly agreement that women are often blamed for infertility as argued by Guntupalli and Chenchelgudem (2004:257), Inhorn (2003:243), Donkor (2008:24) and Papreen et al. (2000:38).

To clarify the argument, the bishops who attended the Imbiza (2013) agreed that:

The church actually recommends that parents who cannot have children because of infertility problems receive parentless children in their home and adopt and bring them up as their own. This is considered a much better option than divorcing the wife deemed infertile and marrying another one, or adding a second wife to bear children. (p. 12)

The fact that the husband divorces his wife or takes a second wife already points to the woman as the root cause of the childlessness. The issue of polygamy and divorce as possible remedies for childlessness is discussed in full by Baloyi (2009:1-15) in his article entitled: 'Critical reflections on infertility in black African Christian communities'. He goes on to articulate that women who cannot bear children face the 'curse of the community' (Baloyi 2009:3). The same opinion is held by Kalu (2005:533) who argues that polygamy is potentially allowed as custom in these circumstances.

It is the purpose of this article to research scholarly arguments that these assumptions are oppressive and subjective towards women. It can be argued that if a couple does not bear children, it is not advisable to blame the woman before thorough medical tests are done. The suggestion of Yamani (2009:21) that infertility is a valid reason for the husband to seek another wife receives support from other scholars like Kofon (1992), Maillu (1988), Cairncross (1974) and Gaskiyane (2000). These scholars agree that the blame for childlessness rests with the wife. This is an unfortunate situation where the man is not suspected. It is the intention of this article to argue how this practice promotes gender inequality.

The praxis notion of theology can only be relevant and helpful if it agrees with the text of the Bible and the context in which we live (Botha 2013:104). Theology, particularly practical theology, should not turn a blind eye while the women of this nation are subjected to continuous and severe stress because of patriarchal attitudes and misunderstandings of conception and childbearing. The Tsonga word for barren Mhika (English-Tsonga Dictionary 2008:150) has such negative connotations that no woman (even the truly barren) is happy to be called that. Although the focus of this article is rooted from the Tsonga speaking people of South Africa, particularly from the Limpopo province, the fact that many black tribes have a lot of traditions in common cannot be avoided. Hence, all African groups that have similar practices and beliefs cannot be avoided in the discussion. It is not always easy to isolate African tribes when attending to their common traditions. There are many forms of childlessness, but for the sake of this article, barrenness, which often comes natural, is intended. The main reason is that this is a natural situation that cannot easily be attributed to someone as a cause. The question of how African people view barrenness will be discussed in the next section.

\section{The African concept and view of barrenness}

In traditional African society a woman was needed as a childbearer and derived her social status and her indispensable value from this position (Imbiza 2013:13). Oduyoye (1995:45) says: 'For Africans, every newborn is an ancestor returned. This belief in reincarnating one's forebearers is seen in the principles underlying the naming of newborns.' Being barren herself, Oduyoye's experience of being childless taught her that motherhood is one of the most important aspects of a woman's life (Siwila 2015:62). According to Rakoma (1995) the Sotho saying:

Teng ga kgomo ga go hlobogwe [literally meaning: Do not give up on the stomach of a cow] implies that if a woman does not bear children, she must not be designated as a barren, she must be taken to traditional doctors to be attended so that she will be able to have children like other women. (p. 219)

The emphasis here is on the woman who should be attended to in cases where children are not conceived. The Swahili proverb: 'A barren wife never gives thanks' (implying that she would have no cause or joy to give thanks) is also echoed by a Gikuyu proverb: 'The woman who has children does not desert her home' (Ritchie 2000:1).

My previous research, entitled 'Critical reflections on infertility in black African Christian communities' (Baloyi 2009:1), focused on how some African people view the issue of infertility. This article aims to research how barrenness becomes a weapon for the oppression and abuse of women, mainly by their husbands and even the in-laws. This gender imbalance issue emanates from our patriarchal system that put men in superior positions to women. In agreement with other African scholars like Kimathi (1994:24), Waruta and Kinothi (2000:102), Mbiti (1991:41) sums up the African view of infertility by saying: 'If there is not yet a child in the marriage there is no guarantee that the marriage will endure.' Marriage and childbearing are regarded as a unit applying pressure on the barren couple. Barrenness is not only unacceptable, but also a disgrace and abnormal state. Even if a man was a migrant worker who usually came home to be with his wife for a short period, for example during the festive season, the family and the community would still expect the woman to conceive a baby. Because children are a glory to the family, barrenness is regarded as a curse and avoided at all costs, resorting to divorce or polygamy. 
The fact that it is the woman who becomes pregnant and carries the baby for nine months before giving birth easily leads people to believe that it is the woman who is responsible for fertility. The reality is that, without a sexual relationship between a man and a woman, no conception can take place. This is easily forgotten by some African traditionalists when trying to promote patriarchy at the expense of women. An interpretation of the creation story by some people causes women to be seen as secondary to men (Mbiti,1988:72). According to Mbiti (1991:89), pregnancy becomes a joyful period for a woman and her family and she should be treated with greater respect than before (Mbiti, 1991:87).

Even though it is not the focus of this article, the misconceptions, misunderstandings and abuse of lobolo that could be summed up by saying 'cattle beget children' made people to think in terms of 'cause and effect' which made childbearing a 'must expectation.' Scholars like Burman (1991:36), Nhlapo (1991:143) and Baloyi (2014:25) support this statement. This is the reason why I agree with African scholars who are against the issue of buying and selling when it comes to lobolo (Mbiti 1969:140; Waruta \& Kinothi 2000:50; Baloyi 2010). This is why, according to Habel (2001:114), the Sotho idiom 'Mosadi a hlaletsa ngwana bolwetsi bo a fola' [When the mother plays with a child her sickness gets healed] becomes a common saying when a child is born. This implies that bearing a child reduces her problems. Even if problems still persist, she will be able to cope with them, because the biggest problem is solved by bearing a child.

The religious view, which emphasises that women must bear children, cannot be ignored. Siwila (2015:63) argues that the story of Hanna in 1 Samuel 1:1-20 reveals how barren women were viewed and mocked in patriarchal times. The fact that Hanna was mocked by her fellow religious sisters puts religion in the spotlight when the issue of barrenness in Christian religion is raised. This mockery is often entrenched in many African tribes in the name of Christianity. In her article entitled 'A coming home to myself', Mercy Oduyoye (1995:46) relates her own story by narrating how the Christian church and African traditional religions were used as tools of oppression against barren women. The fact that Christianity came into Africa as a male-dominated religion does not do anything to reduce the patriarchal male dominance, but rather reinforces it and adds religious validity. This is what Phiri (2007) highlights by saying:

This means that freedom from cultural oppression for African women, as a result of the coming of Christianity, came as a coincidence rather than a formulated understanding of their salvation. (p. 48)

Some African religions regard barrenness as shameful and a punishment of sin (De Wit \& West 2001:191). The same view is shared by Gehman (2002:173) who indicates that barrenness is often listed as a punishment for any anti-social act like jealousy, hatred and so forth. This kind of view demonises barrenness to the extent that even in religious circles it becomes very difficult to break the stigma. Both Christianity and African traditional religions negatively portrayed barrenness and hence they perpetuated the stigmatisation of the barren women through their patriarchal character. This stigmatisation has an impact on the suspected women in few ways as elaborated in the following subsection.

\section{The impact of suspecting women as barren}

Auli Vahakangas (2009:10) points out that: 'The extremely harsh language used regarding women who do not conceive brings shame on the stigmatized wife.' This is because childlessness is a concern of the whole community. It should be noted that, even though marriage is communal in African context, the church should keep teaching that there are some aspects of marriage that the couple should be left to decide alone, for example the number of children to be born. Barrenness in the African context makes a woman feel worthless. One of the possible definitions of self-esteem is 'to value highly' or 'to have a great regard for'. People with a low self-esteem do not regard themselves very highly and do not think they are valuable. Wicks and Parsons (1993:363) see people with a low self-esteem as people who use crutches to walk. They say such people frequently 'see themselves as unworthy or unlovable people who do not deserve genuine, sustained happiness in life'. Collins (1988:318) indicates that one of the causes of low self-esteem is how the community views the person. Collins (1988:320) goes on to argue that ' $[l]$ owered self-esteem and inferiority may contribute to social withdrawal'. In this context the view of the husband and the family as part of a community in Africa can easily spread to other community members. In a communal context it is the community that could either encourage or discourage a person. A woman who is perceived as barren will be discouraged and lose trust in herself and other people. Because Africans believe 'I am, because they are,' according to Scanzoni (1995:51), it is possible that the community, including the church, plays a pivotal role in inflicting damage on a person's self-esteem, particularly the low self-esteem that may result from being pointed at as the cause of misfortune in the family by failing to conceive a baby. In concluding this section, one of the most common struggles today is low self-esteem, and the problem is not limited to any particular economic, social, spiritual, cultural, racial, political or ethnic background (Fagerstrom 1996:69).

Many young people get pregnant before they marry to proof that they can have children. This is one of the reasons why many weddings today involve couples that have been living together and even already have children. It is very rare that young people decide on a wedding before this test has been passed. This is why the question 'How will I tell that the girl can have or will have children before marrying her?' (Kimathi 1983:28) is asked. This kind of question leads to our young boys and girls having sex before marriage ignoring the fact that fornication is a sin in the eyes of God. This conviction leads many young people to risk contracting HIV or AIDS and other sexually transmitted diseases. This is how adultery 
and fornication, which the Bible is strongly against, wrongly gain influence. The TV programme, 'Perfect Wedding', clarifies why many weddings take place after the children have been born and why many young people are resistant to getting married before they are sure of their fertility.

It is also fornication when a male gets a concubine to prove his fertility. There are unproven suspicions that some family members would influence a male to have another relative to have sexual relations with his wife in order to bear children secretly to prevent divorce or separation. Habel (2001:114) indicates this clearly when articulating: 'If it was discovered that a man was infertile, a woman would be encouraged to have sexual relations with somebody outside the marriage, preferably her husband's next of kin.' Cheating and betrayal become common practices if a man believes that the wife is barren. Waruta and Kinoti (2000:106) indicate a case of elopement where men steal each other's wives as well as adultery and sexual promiscuity. Some men are tempted to prove their fertility by impregnating women outside wedlock. This is the kind of practice that can rapidly spread sexually-transmitted diseases like HIV. This impact demands action from the church and the community at large, which leads us to the discussion below.

\section{Proactive and community based interventions}

The principle that the family should accept that children come from God is not an easy one, particularly in a traditional African context. It is, however, the truth that the church must teach through its pastoral services. Whenever there are birthday parties and other child-related events, pastoral caregivers should use these opportunities to make it known to the parents and the family that even though children are born out of the union of the mother and father, the absolute giver of the child is God. In an African context, where 'I am because they are', it is very important that the family and extended family are supportive of the childless couple. It is often the pressure from the extended family that force the husband to the extent that he abuses his wife. The pastoral responsibility is first to help the family members understand the importance of helping and supporting one another even in difficult situations. Another important aspect for the church to highlight is that, although in an African context, it has always been believed that marriage is a communal effort - there are still aspects that must be decided by the couple alone. In such instances, the family must be taught to accept that the extended family should not dictate to the couple. This is what is meant when it is argued that it is sometimes very dangerous for parents and pastors to expect a couple to remain dependent on them after marriage (Baloyi 2014:41). The main argument here is that both parties - parents and the couple - should know their roles when the marriage begins. The parents must be taught to relinquish some power of decision-making to the couple without influencing them.
Husbands must first understand that they are just as responsible for barrenness as their spouses until the facts are medically proven. They need to be protective and supportive towards their wives. A man should also understand that children are gifts from God, and with or without children, the love of the husband and wife must always be encouraged. The loving character of Elkanah towards his barren wife is the example men should follow. We read in the Bible: 'But to Hannah he gave a double portion because he loved her, and the LORD had closed her womb' (1 Sm 1:5). His love for his wife was not conditional on bearing children as it is for many people today. That was the reason why Elkanah also went on to comfort Hannah in her sorrowful prayer, saying: 'Hannah, why are you weeping? Why don't you eat? Why are you downhearted? Don't I mean more to you than ten sons?' (1Sm 1:8). This is the kind of husband every barren woman should expect to have in difficult times, rather than one who joins those who inflict pain to them. The situation is made worse when the allegations of barrenness are based on suspicion without medical proof. The church should not shy away from teaching men to be supportive of their wives regardless of the circumstances.

The church should seek ways to assist and support abused women because of this practice. Practical theology must target barren women who live with an inferiority complex that is brought about by the suspicion that they are the cause of barrenness. It is partly the duty of the church to help the woman regain her self-esteem, dignity and respect of her husband, the family and the community. Pastoral caregivers should help such couples to understand that they should not be quick to judge one another, but they should instead consult with a medical doctor who can advise them of the way forward. Wambugu (2014:1) of The Daily Nation discusses the introduction of the possibility of surrogate motherhood that can be of help to some of them, although it is not very common among black people.

Besides the fact that the church should highlight that children are not the only foundation for a marriage, it should also teach that children are a gift from God. This teaching should be done during premarital counselling and family meetings. A woman should not forget that, even though she was a woman with a womb, it is God who creates human beings that can conceive a baby. According to Imbiza (2013:10), it is correct to teach that children are never and will never become the property of their parents, because they will eventually be released to the freedom of adulthood. In this way the argument that children must be understood as gifts of the Creator, is vital.

The church should also put premarital programmes in place and target issues that can prepare the couple for marriage. It is true that prevention has always been better than cure. For example, it is vital for the couple to know that marriage is not only joyful, but that sorrows are also a part of life and that they need to be ready to deal with those challenging situations. When preparing a couple to face the possibilities 
of unemployment, barrenness and sickness, premarital programmes should also not shy away from teaching against sex before marriage.

It is important to prioritise educational programmes and workshops tailored to each culture's values and traditions in order to eradicate the psychological and economic consequences of infertility. It is also suggested that nations have a reproductive health curriculum to create awareness in as many students as possible at a relatively young age. In order to reverse the stigma and attitudes of this kind, educators and pastoral caregivers should put educational forums in place (Rouchou 2013:175).

It is part of the Christian church's responsibility to redress the traditional and cultural wrongs of the past on issues of marriage, including the way in which barrenness has been misunderstood. The main reason for the church's role is that marriage was initiated by God - the very same owner of the church. Imbiza (2013:40) states: 'When the marital act is no longer required for the conception of children, marriage itself loses its purpose and is no longer the cornerstone for society.' This is where most societies, including Africans, get it wrong in my view. This is a reductionist belief that reduces marriage to mere child-bearing. Before further debating this issue, it needs to be mentioned that when God initiated the very first marriage in Genesis, there were strings attached. The mistake many people make is to read God's blessing when he said: 'Be fruitful and multiply' as a conditional clause for marriage, which it is not. If children are to be understood as gifts from God, the argument of Imbiza (2013:41) and Collins (1988:52) - using barrenness as a reason to dissolve or disrupt a marriage - falls away.

Women are truly more than child-bearers in the family. When a woman was created for man, the Bible uses the argument of loneliness (Gn 2:18), which was to be avoided by getting married. Psychologists have discussed the negative outcomes of loneliness in many instances. In her book Alone in America, Louise Bernikow states that the most difficult thing for any human to admit is loneliness (Fagerstrom 1996:33). In Monoghan (1991:23) Christopher Martins calls loneliness 'the leprosy of the day'. For Keech (1993:73), making love just for fun between times of peak fertility and concentrating on other enjoyable activities, can be helpful.

Men must be discouraged from using the suspicion of barrenness as a means of oppressing and subjecting women to severe violence. The church, through its pastoral teachings, can make use of the opportunity to highlight this message. It is time that many of our citizens, particularly in the rural areas, should be helped to understand that our Constitution seeks to protect women as equal partners with men in life. The awareness that the law of the country will punish them for unreasonably violating women's rights must reach all people. There should be proper channels, like first consulting with doctors and other medical practitioners for tests before unproven blame. Although the church through the centuries has picked up some negative cultural baggage about women, it should advocate that we get rid of the baggage and teach men to start recognising women (wives in particular) as their partners, companions and friends (Imbiza 2013:12). There is no ranking of who are the first or the master when reading 'flesh of my flesh or bone of my bone' in Genesis 1:27. The headship of man as in 1 Corinthians 11:3 and Ephesians 5:23 need its own exegetical study to determine what the meaning for 'head' is. It can, however, be the focus of the next research.

Health professionals who work with these challenges should co-operate with the education system to ensure that education includes organised 'comprehensive educational programmes' that will be geared to educate people on the biological causes of infertility and available treatment options. The collaboration between health professionals, communities and schools can be of assistance by providing information about alternative options such as adoption and artificial insemination. Health practitioners can also help to unmask the pathology that sees men as fertile at all times while women are claimed to be infertile. Youths should also receive their own educational programmes to assist them in avoiding infertility, emphasising the prevention of sexually transmitted infections and the fact that men and women can be infertile for a number of reasons (Donkor 2008:33). Sex education must be part of the school teaching curricula and youth teaching in the church. Bleach, Glencross and Knight (2004:623) clearly explains how the cervix of a woman can be blocked naturally to disturb ovulating which can lead to infertility. This information can be helpful to most people who misunderstand barrenness. It is also argued from Kimathi's point of view (1994:81) that it is possible that the couple fails to conceive due to male or female infertility. Pastoral caregivers should work with communities to reverse teachings such as those of Kimathi (1994:82) who stated: 'Women grow up hearing that a woman's glory is crowned in childbirth.' Community-based pastoral interventions will enable pastors to use every opportunity to teach the young and the old through conferences to understand that being a woman does not necessarily imply being a mother.

The role of women (groups) to support one another is also important in this regard. It was mainly because of the women's support groups that Mercy Oduyoye enjoyed being called 'mama Mercy' regardless of not having her own child (Siwila 2015:70).

Ayankanye (2013:99), in his article 'Pastoral care functional approach as panacea for involuntary childlessness among Christian couples in Africa', gives a beautiful detailed discussion on how pastors can eliminate this challenge by working with both the couple and their families before marriage. He (Ayakanye 2013:98) says: 'Educating is used here in a preparatory sense. This is important to avoid the church being caught unaware if they inevitably become victims of unpleasant marital circumstances.' Besides the church, being a source of both hurt and help, I agree with Evans (2005:580) who understands the church as a community 
of faith where the vulnerable suffering couple can be shown love and acceptance. Ultimately, the church must be prepared to be a home and hope for women who are rejected by their respective families and communities. Finally, healing the wounded barren women should be one of the goals of pastors. Counselling and prayer can be used as tools for healing. Appropriate referral by pastors can also be helpful in this regard if there is a need for it. In fact, the pastor should not try to replace a medical practitioner or try to do things that they are not able to. It is fair and reasonable that after doing their part, pastors should refer people to specialists like nurses, physicians and social workers to collaborate in helping stigmatised women. Oyedele (2012:19) shares the same sentiment when saying: 'The ministry of referral is very essential for holistic approach to existential problem, childlessness inclusive.' As much as it is important for pastors to let people know that it is the will of God for people to procreate (Gn 1:9-25; Dt 7:14), it is equally wrong to insist that one 'must bear children'. It is reasonable to make them understand that their marriage remains complete and acceptable even without children. The church's pastoral activities must be vocal against the stereotypes of seeing women as child-bearers. The liberation theology of James Cone (1982:122), which 'afflicts the oppressor in solidarity with the oppressed', comes to play here. As long as pastors, particularly male pastors, do not show their solidarity with afflicted women by denouncing and challenging males and the community who support these stereotypes, the battle against women oppression will not be won in this context. This is a problem created by patriarchy and therefore men should play a role in reversing the problem. Pastors, in their respective denominations, need to work and teach men that the wrong thinking in terms of barrenness must be corrected. God takes the side of the oppressed (Cone 1975:63).

\section{Conclusion}

The African priority of childbearing as a main purpose for marriage has brought stress and stigma on many couples. Men, because they have been brought up to be rulers and providers of their families in a patriarchal system, are always tempted to believe that they should be exempt from the misfortunes of the family, including a lack of children. Therefore, they are usually quick to judge and shift the blame onto women. It is painful for a woman to be accused of barrenness by the family, but it is even worse if the accusations are also being made by her husband - the one who is supposed to be her protector and supporter. It is the responsibility of practical theology, among other stakeholders, to unveil these unjust practices which, among others, are orchestrated by the abuse and misunderstandings of a patriarchal system that has negative and positive impacts on the lives of African people. The church must, through its pastoral services and teaching, engage in the elimination of this gender-based abuse. There should also be collaboration between the church, the medical fraternity and the government's educational institutions to ensure that old and young people are educated to understand the issue of infertility so as to reduce and eliminate the misunderstandings that often lead to abuse and violence towards women.

\section{Acknowledgements Competing interests}

The author declares that he has no financial or personal relationships which may have inappropriately influenced him in writing this article.

\section{References}

Admin., 2010, 'Statistics on women violence in South Africa: Women in Action', viewed 6 March 2016, from www.womeninaction.co.za

Ayankanye, S.O., 2013, 'Pastoral Care functional approach as panacea for involuntary childlessness among Christian couples in Africa', Journal of Arts and Humanities (JAH) 2(6), 97-104.

Baloyi, M.E., 2009, 'Critical reflections on infertility in black African Christian communities', Practical Theology in South Africa 24(2), 1-15.

Baloyi, M.E., 2010, 'Lobolo in the African community: A critical evaluation' Theologia Viatorum 34(1), 50-70.

Baloyi, M.E., 2012, 'The use of Imago Dei as a pastoral healing vision against women killings in the South African context', Verbum et Ecclesia 33(1), Art. \#703, 6 pages. $\mathrm{http}: / / \mathrm{dx}$.doi.org/10.4102/ve.v33i1.703

Baloyi, M.E., 2013, 'Wife-beating amongst Africans as a challenge to pastoral care', In die Skriflig/In Luce Verbi 47(1), Art. \#713, 10 pages. http://dx.doi.org/10.4102/ ids.v47i1.713

Baloyi, M.E., 2014 'The impact of the extended family on one's marriage: An African study', Journal of Theology for Southern Africa 148, 18-33.

Bleach, E.C, Glencross, R.G. \&Knight, P.G. 2004. 'Association between ovarian follicle development and pregnancy rates in dairy cows undergoing spontaneous oestrous cycles', The Journal of the Society for Reproduction and Fertility 127, 621-629.

Botha, N.A., 2013, 'A theological perspective on migrants and migration focusing on the Southern African Development Community (SADC)', Missionalia 41(2), 104-119.

Burman, S., 1991, 'Illegitimacy and the African family in a changing South Africa', Acto Juridica 21, 36-51.

Cairncross, J., 1974, After polygamy was made a sin. The social history of Christian polygamy, Routledge \& Kegan Paul, London.

Chigudu, H. (ed.), 2004, Composing a new song: Stories of empowerment from Africa, Weaver Press, Harare.

Collins, G.R., 1988, Christian counselling: a comprehensive guide, rev. edn., W Pub Group, Dallas.

Cone, J.H., 1975, God of the oppressed, Seabury Press, New York.

Cone, J.H., 1982, My soul looks back, Abingdon Press, Nashville.

Donkor, E.S., 2008, 'Socio-cultural perception of infertility in Ghana', Africa Journal of Nursing and Midwifery 10(1), 22-34.

De Wit, H. \& West, G. (eds), 2001, African and European Readers of the Bible in dialogue: In quest of a shared meaning, Koninklijke Brill, Leiden, The Netherlands.

English-Tsonga Pocket Dictionary, 2008, Sasavone Publishers, Braamfontein.

Evans, R.O., 2005, 'Infertility', in R.J. Hunter (ed.), Dictionary of Pastoral Care and Counseling pp. 580-595, Abingdon Press, Nashville.

Fagerstrom, D.G., 1996, Counselling single adults: a handbook of principles and advice, Baker, Grand Rapids.

Fidgen, J., 2009, Zambia's celebrity couple reveal wife-beating past, viewed 09 July 2013, from http://news.bbc.co.uk/2/hi/africa/8375291.stm

Gaskiyane, I., 2000, Polygamy: a cultural and biblical perspective, Piquant, London.

Gehman, R.J., 2002, African traditional religion in Biblical perspective', East African Educational Publishers Ltd., Kampala.

Guntupalli, A.M. \& Chenchelgudem, P., 2004, 'Perceptions, causes and consequences of infertility among the Chenchu tribe of India', Journal of Reproduction and Infant Psychology 22(4), 249-259.

Habel, N.C., 2001, The earth story in the Psalms and the prophets, Sheffield Academic Press, Cleaveland.

Imbiza Documentation., 2013, Inter-regional meeting of Bishops of Southern Africa, 10th plenary assembly, document presented at Gaborone, Botswana, 11-15 November.

Inhorn, M.C., 2003, “"The worms are weak": Male infertility and patriarchal paradoxes in Egypt', Men and Masculinities 5(3), 236-256.

Kalu, U.O., 2005, African Christianity: An African story, University of Pretoria Press, Pretoria.

Keech, R., 1993, Better marriage, better life, Halfway House, Southern Book Publishers. Kimathi, G., 1983, Pathway to marriage, Uzima Press, Nairobi.

Kimathi, G., 1994, Your marriage and family, Institute for Reformational Studies, Potchefstroom. (Series F2, 58).

Kofon, N.E., 1992, Polygamy in Pre-Christian Bafut and new moral theological perspectives, Pieter Lang, Frankfurt.

Maillu, D.G., 1988, Our kind of polygamy, Heinemann, Nairobi. 
Mbiti, J.S., 1969, African religions and philosophy, Praeger, New York.

Mbiti, J.S., 1991, Introduction to African religion, Heinemann, Johannesburg.

Mbiti, J.S., 1988, 'The role of women in African traditional religion', Cahiers des Religions Africaines 22, 69-82.

Monoghan, A., 1991, Counselling as a Christian challenge, Gill \& Macmillan, Dublin.

Nhlapo, N.R., 1991, 'The African family and women's rights: Friends or Foes?' Acta Juridica 71,135-146.

Oduyoye, M.A., 1995, Daughters of Anowa: African Women and Patriarchy, Orbis, Maryknoll.

Oyedele, S.O., 2012, Marriage and Family Counseling. Ogbomoso, Amazing Grace Publications, Lagos, Nigeria.

Papreen, N., Sharma, A., Sabin, K., Begum, L., Ahsan, S.K. \& Baqui, A.H., 2000, 'Living with infertility: Experiences among urban slum populations in Bangladesh', with infertility: Experiences among urban
Reproductive Health Matters 8(15), 33-44.

Rouchou, B., 2013, 'Consequences of infertility in developing countries', Environmental and Occupational Health 133(3), 174-179.

Phiri, I.A., 2007, Women, Presbyterianism and Patriarchy. Religious experience of Chewa women in central Malawi, Kachere Series, Zomba.

Phoofolo, P., 2007, 'Holy weddings, unholy marriages: Christian spouses and domestic discords in early colonial Lesotho, 1870-1900', Journal of religious History 31(4), 363-386. http://dx.doi.org/10.1111/j.1467-9809.2007.00688.x

Rakoma, J.R.D., 1995, Marema-ka-dika, Van Schaik, Pretoria.
Ritchie, I.D., 2001, 'African theology and the status of women in Africa', paper presented at the Canadian Theological Society, 5-10 May, viewed 14 March 2016, from www.cts-stc.ca

Scanzoni, J., 1995, Contemporary families and relationships: reinventing responsibility, McGraw-Hill, New York.

Siwila, L.C., 2015, 'The role of indigenous knowledge in African women's theology of understanding motherhood and maternal health', Alteration Special Edition 14, 61-76.

Sophanna, S., 2006, 'Gender, culture and infertility in Cambodian society subjects', $\mathrm{PhD}$ thesis, Department of Health and Social Science, Mahidol University.

Turaki, Y., 1999, Christianity and African gods: a method in theology, Institute for Reformational Studies, Potchefstroom.

Vahakangas, A., 2009, Christian couples coping with childlessness. Narratives from Machame, Kilimanjaro, Pickwick Publications, Eugene. (American Society of Missiology monograph series).

Wambugu, B., 2014, 'A tale of two mothers and surrogate twins', The Daily Nation, 05 July, viewed 03 October 2016, from www.nation.co.ke

Waruta, D.W \& Kinoti, H.W., 2000, Pastoral care in African Christianity, Acton Press, Nairobi.

Wicks, R.J, \& Parsons, R.D., 2003, Clinical handbook of pastoral counselling, vol. 3, Integration Books, New York.

Yamani, M.A.Z., 2009, Polygamy and law in contemporary Saudi Arabia, Ithaca, London. 